\title{
Pengembangan Nilai Karakter Taat melalui Aktivitas Belajar Siswa SMAN 1 Ampel Boyolali
}

\section{Development of Obedient Character Value through Student Learning Activities at SMAN 1 Ampel Boyolali}

\author{
Lisa Virdinarti Putra, Anni Malihatul Hawa, Ika Silfiana Arifatul Khoiriyah \\ Universitas Ngudi Waluyo (UNW), Kabupaten Semarang \\ lisavirdinartiputra@gmail.com, hawa.anni@gmail.com, ikasilfiana@gmail.com
}

Riwayat Artikel: Dikirim 10 September 2018; Diterima 28 November; Diterbitkan 30 November

\begin{abstract}
Abstrak
Tujuan pengabdian ini yaitu melatih siswa untuk memiliki karakter dan etika yang baik, melatih siswa untuk dapat menaati setiap aturan yang diberikan kepadanya melalui aktivitas belajar. Lokasi pengabdian akan dilaksanakan di SMAN 1 Ampel Boyolali melalui Pelatihan dilakukan dengan metode ceramah, presentasi powerpoint, brainstorming, dan dialog. Metode yang digunakan adalah dengan metode partisipatif artinya mitra binaan secara aktif dilibatkan dalam semua tahapan kegiatan pengabdian masyarakat ini. Kegiatan ini menggunakan metode pelatihan yang dilaksanakan selama 3 (tiga) hari dengan materi pelatihan berupa ceramah, praktek, serta evaluasi yang disajikan secara bersamaan. Setelah kegiatan pelatihan, dilanjutkan kegiatan evaluasi sebagai bahan koreksi bagi penyelenggara kegiatan. Hasil evaluasi ini dapat dijadikan sebagai bahan pertimbangan bagi perpustakaan untuk melaksanakan kegiatan serupa terkait dengan kegiatan pendidikan pemakai. Hasil dari pelatihan ini diharapkan siswa memiliki karakter dan etika yang baik supaya siswa dapat menjadi manusia yang tidak hanya bertambah secara usia tetapi juga memiliki kepribadian yang baik seumur hidup.
\end{abstract}

Kata kunci: karakter taat, aktivitas belajar, siswa

\begin{abstract}
The purpose of this service is to train students to have good character and ethics, to train students to be able to obey every rule given to them through learning activities. The service location is implemented at SMAN 1 Ampel Boyolali through training conducted by lecture method, powerpoint presentation, brainstorming, and dialogue. The method used is a participatory method which means that foster partners are actively involved in all stages of this community service activity. This activity uses training methods that is carried out for 3 (three) days with training materials in the form of lectures, practices, and evaluations presented simultaneously. After the training activity, evaluation activities are continued as material for correction to the activity organizers. The results of this evaluation can later be used as consideration for the library to carry out similar activities related to user education activities. The results of this training are expected students to have good character and ethics so that students can become buman beings who not only increase in age but also have a good personality for life.
\end{abstract}

Keywords: obedient character, learning activity, students

\section{PENDAHULUAN}

Karakter sangat dibutuhkan untuk mencapai keberhasilan belajar siswa. Individu yang berkarakter baik adalah individu yang bisa membuat keputusan dan siap untuk mempertanggungjawabkan setiap akibat dari keputusan yang telah dibuat. Siswa Sekolah Menengah Atas adalah siswa siswi yang berusia sekitar 15 sampai dengan usia 17 tahun, merupakan anak yang memasuki transisi perubahan masa anak anak menuju masa remaja yang mana biasanya mereka ingin menunjukan jati dirinya dengan berperilaku meniru idola-idolanya. Cara pembentukan karakter yang baik bagi para siswa agar kelak bisa menjadi warga masyarakat yang berkepribaian baik, yang bersikap dan perilaku religious, toleran, jujur, disiplin, kerja keras, kreatif, tanggung jawab, 
mandiri, demokratis, menghargai karya orang lain dan cinta damai adalah melalui penerapan disiplin tata tertib sekolah.

Pendidikan nasional berfungsi mengembangkan kemampuan dan membentuk watak serta peradaban bangsa yang bermartabat dalam rangka mencerdasakan kehidupa bangsa, bertujuan untuk berkembangnya potensi peserta didik agar menjadi manusia yang beriman dan bertaqwa kepada Tuhan Yang Maha Esa, berakhlak mulia, sehat, berilmu, cakap, kreatif, mandiri, dan menjadi warga negara yang demokratis serta bertanggung jawab. (Undang-Undang Nomor 20 tahun 2003). Lembaga pendidikan sebagai tempat pembentukan karakter peserta didik dituntut untuk meningkatan intensitas dan kualitas pelaksanaannya. Tuntutan tersebut didasarkan pada fenomena sosial yang berkembang, yakni meningkatnya kenakalan remaja di masyarakat mulai dari tawuran, pengeroyokan, pencurian, perampokan dan tindakan asusila. Fenomena tersebut telah pada taraf yang meresahkan. Oleh karena itu lembaga pendidikan sebagai wadah resmi pembinaan generasi muda diharapkan dapat meningkatkan peranannya dalam pembentukan kepribadian peserta didik di samping keluarga dan masyarakatPentingnya pendidikan karakter pada usia dini yang diberikan oleh orang tua yang berbasis pada kearifan lokal dapat menumbuhkembangkan anak menjadi cerdas secara intelektual, spiritual, dan emosial yang lebih insan dan berkarakter. Golden age yaitu sebuah masa keemasan usia seorang anak dimana periode masa keemasan ini hanya datang satu kali saja seumur hidup yang tidak dapat diulang lagi. Karena pentingnya usia emas ini pemberian pengalaman dan didikan karakter pada seorang anak dari orang tua maupun guru di sekolah sangatlah penting karena dapat membekas yang sangat kuat dan tahan lama dalam pribadi anak. Dan pada tingkat perkembangan selanjutnya karakter anak berkembang kearah yang lebih baik dan semakin kuat.

Menurut Vigotsky, aktivitas mental yang tinggi pada anak dapat terbentuk melalui interaksi dengan orang lain. Pembelajaran yang berkarakter akan menjadi pengalaman yang bermakna bagi anak jika ia dapat melakukan sesuatu (baik itu merubah atau mengikuti) atas lingkungannya. Anak merupakan aset yang menentukan kelangsungan hidup, kualitas dan kejayaan suatu bangsa di masa mendatang. Oleh karena itu anak perlu dikondisikan agar dapat tumbuh dan berkembang secara optimal dan dididik sebaik mungkin agar di masa depan dapat menjadi generasi penerus yang berkarakter serta berkepribadian baik. Keluarga adalah lingkungan yang pertama dan utama dikenal oleh anak. Karenanya keluarga sering dikatakan sebagai primary group. Alasannya, institusi terkecil dalam masyarakat ini telah mempengaruhi perkembangan individu anggotaanggotanya, termasuk sang anak. Kelompok inilah yang melahirkan individu dengan berbagai bentuk kepribadiannya di masyarakat. Oleh karena itu tidaklah dapat dipungkiri bahwa sebenarnya keluarga mempunyai fungsi yang tidak hanya terbatas sebagai penerus keturunan saja. Mengingat banyak hal-hal mengenai kepribadian seseorang yang dapat dirunut dari keluarga. Tingkat pendidikan orang tua secara tidak langsung akan mempengaruhi kelangsungan pendidikan anak. Pendidikan orang tua terhadap anak-anaknya adalah pendidikan yang didasarkan pada rasa kasih sayang terhadap anak-anak, dan yang diterimanya dari kodrat. Orang tua adalah pendidik sejati, pendidik karena kodratnya. Oleh karena itu, kasih sayang orang tua terhadap anak-anak hendaklah kasih sayang yang sejati pula, yang berarti pendidik atau orang tua mengutamakan kepentingan dan kebutuhan anak-anak dengan mengesampingkan keinginan dan kesenangan sendiri. diperlihatkan dalam pelaksanaan kegiatan ini yakni latar belakang keluarga yang berbeda-beda yang secara tidak langsung berdampak pada 
sikap atau karakter mereka, baik itu latar belakang dari segi pekerjaan, pendidikan.

\section{METODE}

Sasaran kegiatan pengabdian kepada masyarakat adalah siswa kelas XII SMA NEGERI 1 Ampel. Metode kegiatan yang dilakukan dalam pengabdian masyarakat ini adalah dengan metode partisipatif artinya mitra binaan secara aktif dilibatkan semua dalam semua tahapan kegiatan pengabdian masyarakat ini.

Berangkat dari permasalahan yang muncul disusun berbagai alternatif untuk memecahkan masalah. Dari berbagai alternatif, dipilih alternatif yang paling mungkin dilaksanakan.

Tabel 1:

Tahapan-tahapan Kegiatan

\begin{tabular}{|c|l|l|}
\hline No & \multicolumn{1}{|c|}{ Tahapan } & \multicolumn{1}{c|}{ Kegiatan } \\
\hline 1 & Tahap I & Persiapan : perizinan, persiapan bahan dan materi \\
\hline 2 & Tahap II & Memberikan materi pelatihan \\
\hline 3 & Tahap III & Praktek strategi pencarian informasi \\
\hline 4 & Tahap IV & Evaluasi dan tindaklanjut \\
\hline 5 & Tahap V & Pelaporan hasil dan publikasi \\
\hline
\end{tabular}

Tabel 2:

Luaran

\begin{tabular}{|c|l|c|c|}
\hline No & \multicolumn{1}{|c|}{ Jenis Luaran } & $\begin{array}{c}\text { Tahun } \\
\text { Capaian }\end{array}$ & Status Capaian \\
\hline Luaran Wajib & 2018 & Ada peningkatan \\
\hline 1 & $\begin{array}{l}\text { Peningkatan aktivitas belajar siswa melalui } \\
\text { pengembangan karakter taat }\end{array}$ & 2018 & Accepted \\
\hline 2 & $\begin{array}{l}\text { Artikel ilmiah yang dipublikasikan di } \\
\text { Jurnal Nasional }\end{array}$ & \\
\hline
\end{tabular}

\section{Langkah-langkah}

Pada tahap awal pengabdian ini dengan melakukan izin pada kepala sekolah SMAN 1 Boyolali, mempersiapkan materi mengenai pengembangan nilai karakter taat berupa pree-test, post-test, materi yang akan disampaikan kepada siswa mengenai karakter taat. Kegiatan pengabdian kepada masyarakat yang dilaksanakan dengan metode pelatihan, monitoring dan evaluasi tentang karakter taat di SMAN 1 Ampel. Kegiatan ini dilakukan dengan cara tatap muka selama empat kali pertemuan dengan durasi $2 \mathrm{jam} /$ pertemuan. Siswa mendengarkan pelatihan mengenai karakter taat dan memberikan pertanyaan kepada siswa terkait ketaatan yang dilakukan. Evaluasi dari kegiatan ini menekankan pada proses dan hasil. Penilaian proses dilakukan pada saat siswa mendengarkan ceramah. Melalui pertanyaan dan keseriusan siswa akan diperoleh bagaimana antusiasme dan kebermanfaatan kegiatan ini. Akan dievaluasi juga tentang pengetahuan siswa tentang pengalaman yang dilakukan siswa saat aktivitas belajar.

Kegiatan ini menggunakan metode pelatihan yang dilaksanakan selama 4 (empat) hari dengan materi pelatihan berupa pre-test, pelatihan materi (ceramah), post-test, serta evaluasi yang disajikan secara bersamaan. Setelah kegiatan pelatihan, akan dilanjutkan kegiatan evaluasi sebagai bahan koreksi bagi penyelenggara kegiatan. Hasil evaluasi ini nantinya dapat dijadikan sebagai bahan pertimbangan bagi perpustakaan untuk melaksanakan kegiatan serupa terkait 
dengan kegiatan pendidikan pemakai. Adapun penjabaran langkah-langkahnya sebagai berikut:

a. Analisis situasi dengan menyebar survey karakter taat kepada siswa.

b. Persiapan pengabdian masyarakat meliputi perizinan, persiapan bahan dan materi.

c. Pelatihan ini dilakukan dengan cara presentasi materi terkait dengan pengembangan nilai karakter taat.

d. Praktek strategi karakter taat melalui aktivitas belajar siswa.

e. Monitoring dan evaluasi.

f. Pelaporan hasil pelaksanaan kegiatan dan publikasi pengabdian masyarakat.

Kegiatan pengabdian masyarakat ini meliputi empat kegiatan yaitu :

a. Memberikan pree-test kepada siswa mengenai karakter taat melalui angket.

b. Pelatihan melalui presentasi menggunakan powepoint untuk memberikan materi berupa karakter taat pada siswa untuk meningkatkan aktivitas belajar.

c. Memberikan post-test kepada siswa setelah diberikan pelatihan berupa karakter taat untuk meningkatkan aktivitas belajar melalui angket.

d. Monitoring dan evaluasi yaitu kegiatan yang mem-follow up dari kegiatan yang pernah dilakukan sehingga pelaksana menemukan temuan-temuan yang dapat digunakan sebagai bahan pertimbangan/perbaikan ketika melaksanakan kegiatan pengabdian.

\section{HASIL DAN PEMBAHASAN}

Kegiatan pertama yaitu membagikan angket kondisi awal siswa yang dilaksanakan pada hari Kamis tanggal 22 Februari 2018 pukul 09.00-11.00. dan pelatihan pada hari Kamis 29 Maret 2018. Peserta kegiatan berjumlah 31 orang. Kegiatan ini dilakukan oleh 3 orang tim pelaksana dengan pokok bahasan yang disampaikan adalah mengenai pengembangan karakter taat untuk meningkatkan aktivitas belajar (tingkah laku, kedisiplinan, cara belajar, cara menghadapi permasalahan dalam hal belajar yang dirasa kurang kondusif)

Kegiatan ini diawali dengan presentasi berupa ceramah tentang apa itu karakter taat. Narasumber memberikan masukan mengenai cara belajar siswa SMA dilihat dari cara berperilakunya. Contoh halnya adalah kejujuran dalam setiap kegiatan belajar di lingkungan sekolah. Dengan membiasakan diri berlaku jujur, maka siswa akan terhindar dari tindakan kurang terpuji. Selain itu juga diberikan paparan mengenai apa itu yang dimaksud dengan karakter taat. Siswa dituntut untuk belajar melakukan apa saja sesuai dengan hati nurani yang baik, belajar untuk disiplin dalam hal apa saja. Selain itu, pembicara kedua juga mengajarkan bagaimana berperilaku yang baik. Pada sesi tanya jawab, sebagian besar siswa antusias menjawab pertanyaan yang diberikan.

Kegiatan kedua yang dilaksanakan pada hari Selasa tanggal 10 April 2018 pukul 10.30-12.30. Peserta kegiatan berjumlah 31 orang artinya bahwa semua peserta yang menjadi sasaran kegiatan pengabdian hadir 100\%. Kegiatan kedua ini adalah pelatihan untuk berperilaku taat. Pelatihan dilakukan dengan metode ceramah dan latihan. Dengan cara ini, siswa dapat langsung melakukan contoh tindakan yang dijelaskan oleh pelatih. Dalam pelatihan, siswa akan didampingi oleh pelatih beserta tim sekaligus dapat mengemukakan pertanyaan terkait dengan materi yang sedang berlangsung.

Kegiatan pelatihan ini berakhir siswa mengerti tindakan apa yang harus dilakukan yang sesuai dengan hati nurani yaitu tindakan yang baik.

Kegiatan ketiga adalah monitoring dan evaluasi (monev) yang dilakukan pada hari Selasa 5 Mei 2018. Kegiatan ini memfollow up dari kedua kegiatan yang telah dilakukan sebelumnya. Pelatihan yang dilakukan secara umum telah berlangsung baik dan lancar. Tingkat penyerapan siswa 
terhadap pemaparan yang diberikan oleh kedua pelaksana cukup baik dilihat dari antusiasme peserta dalam bertanya terkait materi yang diberikan oleh pelaksana. Kasus-kasus yang dikemukakan oleh pelaksana ditanggapi dengan menanyakan kembali hal-hal yang terkait. Melalui sesi tanya jawab, panitia dapat melakukan pengukuran (assessment) terhadap kegiatan ini.

Mengingat pelatihan ini disambut dengan antusias oleh siswa, pelatihan seperti ini dapat dijadikan kegiatan rutin di sekolah sehingga siswa termotivasi untuk hidup taat.

Dengan demikian diharapkan kegiatan pengabdian kepada masyarakat pada Skim Ipteks bagi Masyarakat (IbM) tahun anggaran 2018 ini bermanfaat dalam menjadikan perilaku siswa untuk meningkatkan aktivitas belajar dengan lebih baik selain itu juga dapat meningkatan tingkah laku yang positif, kedisiplinan yang baik, cara belajar positif, cara menghadapi permasalahan dalam hal belajar yang dirasa kurang kondusif Pemberian pengabdian diharapkan menjadi proses penyaluran Ilmu Pengetahuan kepada masyarakat yang lebih bermanfaat.

\section{KESIMPULAN}

Berdasarkan uraian pada hasil dan pembahasan di atas, maka dapat disimpulkan sebagai berikut.

1. Pelaksanaan kegiatan pengembangan karakter taat di SMAN 1 Ampel meningkatkan pemahaman dalam menanamkan sikap yang baik saat di lingkungan sekolah maupun bermasyarakat.

2. Melatih siswa untuk memiliki karakter dan etika yang baik, melatih siswa untuk dapat menaati setiap aturan yang diberikan kepadanya melalui aktivitas belajar.

3. Faktor penghambat yang diperlihatkan dalam pelaksanaan kegiatan ini yakni latar belakang keluarga yang berbedabeda yang secara tidak langsung berdampak pada sikap atau karakter mereka, baik itu latar belakang dari segi pekerjaan, pendidikan.

4. Faktor pendukung guru dalam menerapkan kegiatan pengembangan karakter taat ini sangat menolong peserta didik pada umumnya. Walaupun tidak banyak menolong tetapi sangat memberi dampak perubahan pada siswa khusunya pada aktivitas belajar mereka.

\section{DAFTAR PUSTAKA}

Yuliati, L. (2014). Pembentukan Karakter Anak. Jakarta: Agate

Poerwandari. (2008). Metode Penelitian Pendidikan. Bandung: Al-Fabeta.

Rasyid, H. (2000). Metode Penelitian Kualitatif Bidang Ilmu Sosial dan Agama. Pontianak: Kopma STAIN.

Sugiyono. (2008). Metode Penelitian Administrasi. Bandung, Alfabeta.

Slamento. (2005). Belajar dan Faktor-faktor yang Mempengarubinya. Jakarta: Renika Cipta. 